\title{
Screening Tomato Genotypes for Bacterial Wilt Disease (Ralstonia solanacearum) Resistance in Ghana
}

\author{
Isaac Newton B-Mensah, Kingsley Osei, and Ruth N. A. Prempeh
}

\section{ABSTRACT}

\begin{abstract}
Thirteen-tomato genotypes were assembled from the USA, Taiwan and Ghana for screening for bacterial wilt resistance in two environments: in a screen house at Crops Research Institute, Kumasi, Ghana and in the field at a bacterial wilt hot spot at Bechem in the Brong-Ahafo region of Ghana. The bacterium, Ralstonia solanacearum was isolated using the serial dilution method on Nutrient Agar (NA) and aseptically cultured for inoculation. The bacterium was implicated as the causal organism of the bacterial wilt disease of tomato. A local check, Petofake and $\mathbf{H 7 9 9 6}$ were used as susceptible and resistant checks respectively. Three genotypes, H7996, LA0442 and LA0443 demonstrated significant resistance stability in both experimental environments by recording significantly low wilt incidence and severity. H7996 was obtained from the World Vegetable Centre (WVC), Taiwan while the other two genotypes were collected from the University of California, Davis, USA. Apart from the highest yielding genotype LA 0442 that recorded $50.67 \mathrm{t} / \mathrm{h}$, the rest recorded very low yields. The lowest yielding genotype AVTO 1713, recorded $(12.67 \mathrm{t} / \mathrm{h})$. Thus, the highest yielding genotype, LA 0442 over-yielded the lowest AVTO1713 by approximately 300\%. It is instructive to note that LA0442, which was identified as a stable resistant genotype also recorded the highest yield. This result supports the potential of developing a resistant, high yielding variety using LA0442 as a parent. The future of the tomato industry in Ghana therefore looks promising.
\end{abstract}

Keywords: Tomato, bacterial wilt disease, Ralstonia solanacearum, resistance, Ghana.

\section{INTRODUCTION}

Tomato is one of the most popular and extensively consumed vegetable crops all over the world. It is a key component in the diets of Ghanaian households. Approximately, 440,000 tons of tomato are consumed annually, equivalent to $40 \%$ of household vegetable expenditure [1]. In the culinary industry, not only are tomatoes used in salads, but they are also essential part of many recipes as well as many products such as tomato ketchup and tomato paste. Previous authors [2] have provided a thorough nutritional profile of several tomato genotypes. Tomatoes represent by far the main source of lycopene, whereas many other dietary sources contribute to the daily intake of beta-carotene. In addition, the tomato fruit is a reservoir of other potentially healthy molecules, such as ascorbic acid, vitamin $\mathrm{E}$ and phenolic compounds, particularly flavonoids [3], [4]. Pharmaceutically, the consumption of tomato reduces heart disease, lowers blood pressure, reduces migraines, protects cell damage, and boosts immunity [5].

Major constraints to the production of tomato include pests and diseases pressure in the nursery and on the field [6]. Among the several pathological problems affecting tomato
Submitted : April 05, 2021

Published : September 02, 2021

ISSN: $2684-1827$

DOI: $10.24018 /$ ejfood.2021.3.5.277

Isaac Newton B-Mensah

CSIR - Crops Research Institute, Box 3785, Kumasi, Ghana.

Kingsley Osei*

CSIR - Crops Research Institute, Box 3785, Kumasi, Ghana.

(e-mail: oseikingsley4@gmail.com)

Ruth N. A. Prempeh

CSIR - Crops Research Institute, Box 3785, Kumasi, Ghana.

*Corresponding Author crop, the bacterial wilt disease caused by Ralstonia solanacearum is a devastating threat in warm climates worldwide [7]. The bacterium, $R$. solanacearum is rodshaped without spore formation and gram negative when gram stained. It is a facultative parasite of economic importance infecting about 200 plant species in over 40 families which include a wide range of ornamentals, weeds, and crop plants such as tomatoes, egg plants, peppers, and sweet potato [8], [9]. The bacterium is soil borne, causing sudden death and stem rot of plants [10].

The bacterium can survive in soil for extended periods without a host plant [11]. In addition, the pathogen can persevere in uneven stages in water, plant residues, rhizosphere and within the host plant [12], [13]. These attributes of the bacterium make the disease very difficult to manage. According to [14] the disease was first reported in Ghana during genetic diversity of tomato germplasm studies. Different management strategies of the disease include chemical, cultural, and biological methods. High cost, environmental degradation and ineffectiveness among other reasons render these strategies unsustainable. Development of bacterial wilt-resistant cultivars appears a sustainable approach to manage the disease [15].

The objective of this study was to identify resistant tomato genotypes that can be incorporated into the tomato breeding 
program at the Crops Research Institute in Kumasi, Ghana. Therefore, 13 genotypes were assembled and evaluated for resistance to bacterial wilt disease. Resistant tomato genotypes identified would be introgressed into susceptible but high yielding varieties in Ghana for enhanced productivity.

\section{MATERIALS AND MethodS}

A. Isolation and Identification of the Bacterium Associated with Wilt of Tomato ( $R$. solanacearum)

Five samples each (a total of twenty) of tomato plants showing symptoms of wilting were uprooted together with rhizosphere soil from farms in Agogo and Akumadan (in Ashanti region) and Bechem and Tuobodom (in Brong Ahafo region) of Ghana for isolation of the bacterium. The serial dilution method of isolation on Nutrient Agar (NA) was employed. One (1) $\mathrm{g}$ of the sample was dissolved in $10 \mathrm{ml}$ of sterile water to make suspensions. Portions of the suspensions were inoculated on the NA by streaking and were incubated at $37{ }^{\circ} \mathrm{C}$ for $24 \mathrm{~h}$ after which colonies with a clear zone of inhibition were observed. After serial dilution, identification was done by grouping colonies and counting using the colony counter, and then each colony was subcultured unto a $9 \mathrm{~cm}$ Petri dish containing NA to obtain pure cultures. The pure culture of the pathogen was obtained by the single hyphal tip technique and the culture was maintained on peptone slants to carry out further studies. Slides for microscopic examination of the bacterium were prepared by gram staining and examined under a compound microscope at low and high magnifications for the structure of the bacterium. The identification of the bacterium was based on colour and morphology as described by [16] and $R$. solanacearum was confirmed.

\section{B. Tomato Genotypes Used in the Resistance Study}

Thirteen (13) tomato genotypes sampled from three countries were screened for resistance to bacterial wilt disease. Five of the genotypes were collected from the United States of America (USA), another five from Ghana where the study was conducted and three from Taiwan. Table 1 profiles the genotypes used in the study.

TABLE 1: CHARACTERISTICS OF GENOTYPES USED IN THE STUDY

\begin{tabular}{ccc}
\hline Genotype & Source & Country \\
\hline LA0376 & $\begin{array}{c}\text { University of } \\
\text { California, Davis } \\
\text { University of } \\
\text { California, Davis } \\
\text { University of } \\
\text { California, Davis } \\
\text { LAniversity of } \\
\text { LA0442 }\end{array}$ & USA \\
California, Davis & USA \\
LA0443 & University of \\
H7996 & California, Davis & USA \\
AVTO 1713 & WVC & USA \\
AVTO 1717 & WVC & Taiwan \\
CRI-ATS06 & WVC & Taiwan \\
CRI-P005 & CSIR-CRI & Taiwan \\
Power & CSIR-CRI & Ghana \\
Konkon & Farmer Field & Ghana \\
Petofake & Farmer Field & Ghana \\
\hline
\end{tabular}

WVC $=$ World Vegetable Centre; CRI=Crops Research Institute; $\mathrm{CSIR}=$ Council for Scientific and Industrial Research

\section{Evaluation of Bacterial Wilt Resistance in the Screen House}

The seeds of the 13 tomato genotypes were nursed in plastic seed trays after filling the trays with universal potting medium obtained from Dizengoff Ghana Ltd. Extreme care was taken not to mix the seeds up (Fig. 1). In every cell of the tray, a seed of tomato was nursed, they were well labelled and watered daily till emergence of seedlings after which watering was done as and when needed to avoid damping-off. In addition, Dean an insecticide (Emamectin benzoate + imidacloprid) at $40 \mathrm{ml} / 15 \mathrm{~L}$ of water and Mancozeb, a fungicide (Ethylene bisdithiocarbamate) at $100 \mathrm{~g} / 10 \mathrm{~L}$ of water were timely applied to keep the seedlings healthy for transplanting.

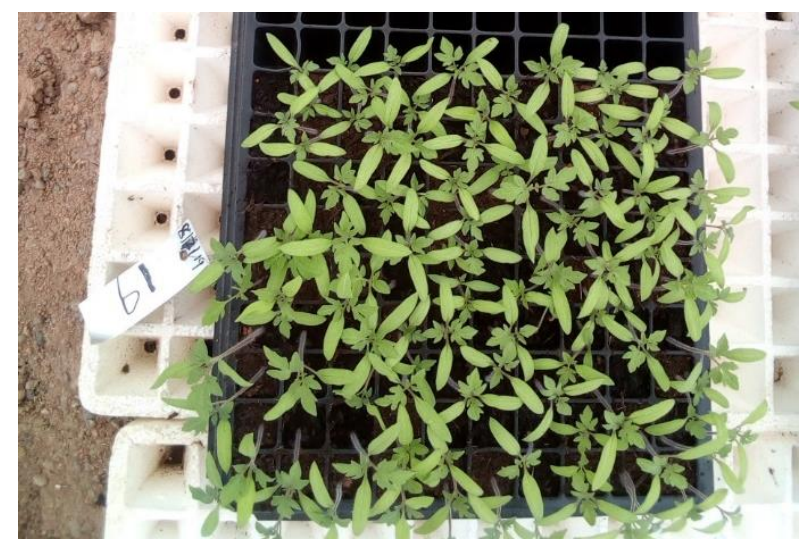

Fig. 1. Genotypes nursed in plastic seed tray for transplanting and eventual inoculation with $R$. solanacearum suspension.

\section{Inoculum Preparation, Inoculation and Transplanting of Tomato Seedlings into Pots}

Pure culture of $R$. solanacearum, isolated as previously described was cultured on nutrient broth for $48 \mathrm{~h}$ at $30{ }^{\circ} \mathrm{C}$. The bacterial suspension was prepared from the cultures where the inoculum dosage was adjusted to an optical density of 0.3 at $600 \mathrm{~nm}\left(10^{8} \mathrm{cfu} / \mathrm{ml}\right)$ using spectrophotometer. The bacterial suspension was used to inoculate the tomato seedlings using the root dip method. Twenty-one day old healthy seedlings from the nursery trays had their root tips cut to about $10 \mathrm{~mm}$ creating wounds to serve as entry points for the inoculum (pathogen). After wounding the plants, the seedlings were dipped in the bacterial suspension that contained mainly, $R$. solanacearum for $15 \mathrm{~min}$ [17] before transplanting into pots containing well sterilized soil (black soil collected from an old refuse dump mixed with river sand in a ratio of 3:1). Meanwhile three seedlings each of the genotypes were used as control treatments that had their root tips cut without inoculating with the $R$. solanacearum but rather dipped into distilled water for $15 \mathrm{~min}$. Regular cultural practices and plant protection measures were carried out as recommended. The experiment was laid out in a Completely Randomized Design (CRD) involving the 13 genotypes profiled in Table 1. Treatments were replicated three times having ten (10) plants per replication. Bacterial wilt resistant tomato genotype (H7996) according to [18] and susceptible tomato genotype (Petofake) were used as checks in the screen house experiment. The screen house experiment was performed for a four-week period. 


\section{E. Evaluation of Bacterial Wilt Resistance in the Field}

Twelve (12) genotypes instead of 13 were evaluated in the field for confirmation of the results obtained from the screen house experiment. A foreign genotype LA0716 which recorded significantly high incidence and severity levels in the screen house experiment was eliminated. The genotypes comprised; H7996 as a stable resistant check and Petofake as a susceptible check. This activity was conducted in a bacterial wilt hot spot at Bechem in the Brong-Ahafo region of Ghana. Seeds for the field evaluation were nursed in plastic seed trays as stated in the screen house experiment and all nursery cultural practices and plant protection measures were carried out to raise healthy seedlings. The experimental area was slashed, ploughed, and harrowed to pulverize the soil to a good tilth. A Randomized Complete Block Design (RCBD) with three replications was adopted. To confirm the resistance in the selected genotypes, twenty-one day old seedlings were similarly inoculated as in the screen house experiment using pure isolates of $R$. solanacearum (Fig. 2). The inoculated seedlings were then transplanted to the field. Seedlings were gently removed from the trays and planted on their respective plots followed by watering of each transplanted seedling. A plot consisted of three rows of eight plants each making a total of 24 plants per plot. A spacing of $40 \mathrm{~cm} \times 80 \mathrm{~cm}$ was maintained. Data was taken on six plants from the central rows. Individual plots were carefully labelled to prevent mixup of treatments. Transplanting was done late in the afternoon for avoidance of heat shock. Field management, regular cultural practices and plant protection measures were carried out as recommended.

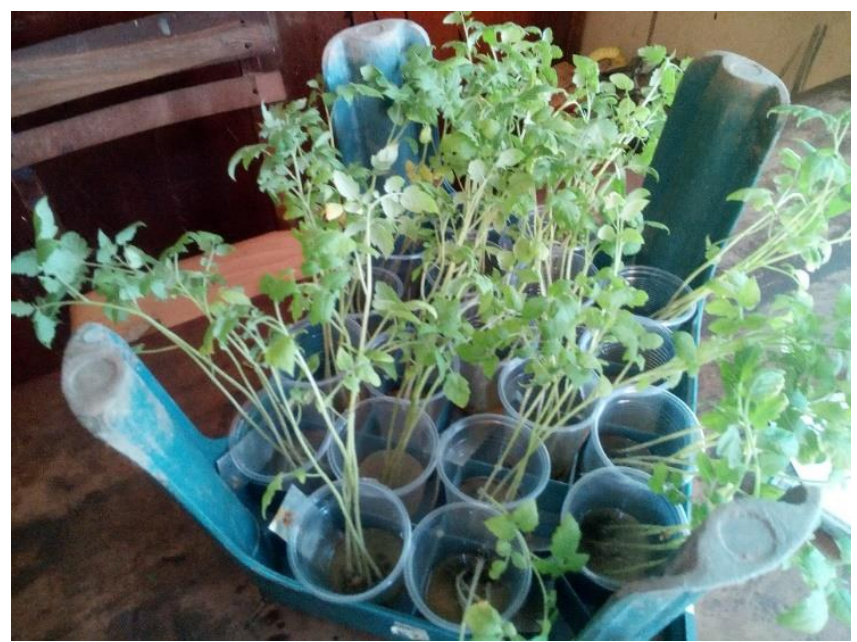

Fig. 2. Seedlings inoculated with $R$. solanacearum suspension.

A week after transplanting, Mono Ammonium Phosphate (MAP) granules were mixed in water and applied to seedlings (sprayed) at $50 \mathrm{~g}$ per $15 \mathrm{~L}$ of water to promote root establishment. In addition, an insecticide, Dean (Emamectin benzoate + imidacloprid) was applied to prevent crickets and other insects from attacking the seedlings. After a week, Yara Winner N: P: K (supplied by Wienco Gh Ltd) was applied at a rate of $5 \mathrm{~g}$ per plant. Diathane M-45, a contact fungicide (Dihiocarbamate) at $225 \mathrm{~g} / 15 \mathrm{~L}$ of water and Yara Nitrabor (Sulphate of Ammonia) at $5 \mathrm{~g} /$ plant were also applied two weeks later. Subsequently, Protect, an insecticide (Emamectin benzoate + Imidacloprin) and Victory, a fungicide (Ethylene bisdithiocarbamate $+\mathrm{N}-$ (2, 6-
dimethyphenyl)-N (methoxyacetyl) were sprayed alternatively to control insect pests and diseases at weekly intervals. Four weeks after transplanting, earthing-up of plants was done to support plants and increase moisture retention.

\section{F. Data Collection and Analysis}

Plants showing signs and symptoms of bacterial wilt in the screen house experiment were randomly scored based on incidence and severity. Disease incidence was calculated using a

disease index percent $(\%)=($ Number of wilted plant $/$
Total number of inoculated plants $) \times 100$,

whilst severity was evaluated based on a 0-4 disease scale [19].

where:

$0=$ no symptoms of wilting;

$1=1$ to $25 \%$ of plants wilting;

$2=26$ to $50 \%$ of plants wilting;

$3=51$ to $75 \%$ of plants wilting;

$4=76$ to $100 \%$ of plants wilting.

Percentage of wilted plants on incidence and severity was arcsine transformed and subjected to Analysis of Variance (ANOVA) to evaluate the levels of resistance among the genotypes using GenStat vs. 14 software with Standard Error of Difference (SED) test at 5\% for means separation.

Regarding the field evaluation, six plants were randomly selected from the middle row of each plot and tagged for data collection. Data collected included days to $50 \%$ flowering, days to fruit setting, plant height, stem girth, number of fruits per plot, weight of fruits, and brix (Total soluble solids). Plant height and stem girth were measured with a tape measure and a pair of callipers respectively. Number of days to $50 \%$ flowering and fruit setting were counted (from the first day till when one half the population of plants flowered and set fruit) respectively, while number of fruits per plot was counted till harvest. The weight of fruits per plot was determined with a measuring scale. Total soluble solids (TSS) of fruits were determined with a refractometer. Data was subjected to Analysis of Variance (ANOVA) to evaluate the levels of resistance among the genotypes in reaction to their agronomic characteristics using GenStat vs. 14 software. Means were separated using the Standard Error of Difference (SED) test at $5 \%$ level of significance.

\section{RESULTS}

\section{A. Field Evaluation}

1) Ralstonia solanacearum isolates encountered among the genotypes in the field

Five different isolates, all negative gram stained, and rod shaped were identified from the genotypes studied. They presented varying purity levels ranging from 1.23 to 2.09 (Table II).

The five isolates identified were White Irregular (WI), White Circular Small (WCS), Cream Irregular (CI), Irregular (I) and White Circular Large (WCL) (Plate 1). 
TABLE II: BACTERIAL WILT (R. SOLANACEARUM) ISOLATES IDENTIFIED

\begin{tabular}{ccccccc}
\hline $\begin{array}{c}\text { Sample } \\
\text { code }\end{array}$ & $\begin{array}{c}\text { Regional } \\
\text { code }\end{array}$ & Status & Source & Purity & $\begin{array}{c}\text { Gram } \\
\text { stain test }\end{array}$ & $\begin{array}{c}\text { Cell } \\
\text { appearance }\end{array}$ \\
\hline 1 & BA 1 & WCL & Plant & 1.67 & - & Rod shaped \\
2 & BA 2 & WCS & Soil & 1.82 & - & Rod shaped \\
3 & BA 3 & WI & Plant & 2.04 & - & Rod shaped \\
4 & BA 4 & CI & Poil & 2.02 & - & Rod shaped \\
5 & BA 5 & CI & Soil & 2.07 & - & Rod shaped \\
6 & BA 6 & WI & Soil & 2.06 & - & Rod shaped \\
7 & BA 7 & WCS & Plant & 1.95 & - & Rod shaped \\
8 & BA 8 & WI & Soil & 2.07 & - & Rod shaped \\
9 & BA 9 & I & Plant & 2.09 & - & Rod shaped \\
10 & BA 10 & WCS & Soil & 2.02 & - & Rod shaped \\
11 & Ash 1 & WII & Plant & 2.03 & - & Rod shaped \\
12 & Ash 2 & WCL & Plant & 2.02 & - & Rod shaped \\
13 & Ash 3 & CI & Soil & 1.88 & - & Rod shaped \\
14 & Ash 4 & I & Plant & 1.99 & - & Rod shaped \\
15 & Ash 5 & I & Soil & 1.98 & - & Rod shaped \\
16 & Ash 6 & WI & Soil & 2.07 & - & Rod shaped \\
17 & Ash 7 & WI & Plant & 1.23 & - & Rod shaped \\
18 & Ash 8 & CI & Soil & 1.77 & - & Rod shaped \\
19 & Ash 9 & WCS & Plant & 1.89 & - & Rod shaped \\
20 & Ash 10 & &
\end{tabular}

Regional code: $\mathrm{BA}=$ Brong Ahafo; $\mathrm{Ash}=$ Ashanti. Bacteria status: $\mathrm{WCL}=$ White circular large; WCS $=$ White circular small; WI $=$ White irregular; CI $=$ Cream irregular; $\mathrm{I}=$ Irregular.

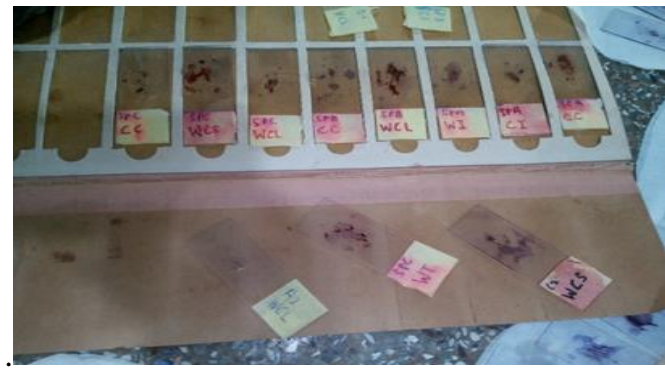

(a)

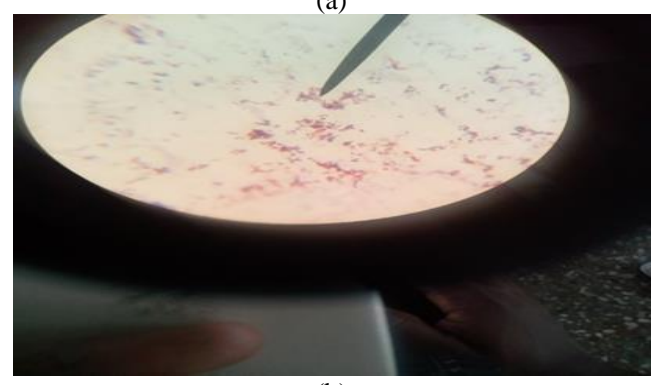

(b)

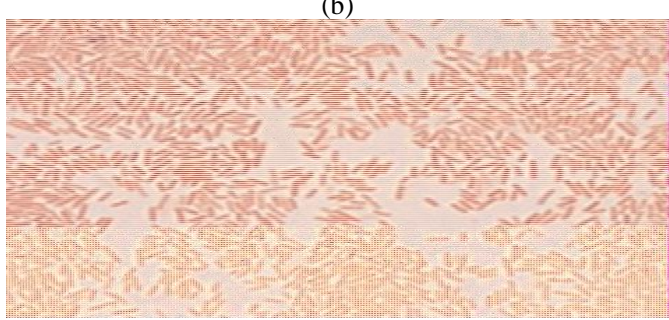

(c)

Plate 1. Microscopic morphological representation of Ralstonia solaneacerum after gram staining (a to $\mathrm{c}$ ).

\section{B. Screen House Evaluation of Tomato Genotypes for BW Resistance}

The experiment revealed that among the genotypes, there were no significant $(p>0.05)$ differences at week one of incubation. However, significant $(\mathrm{p}<0.05)$ differences were observed among the genotypes at weeks two, three and four of incubation (Tables II and III). After week four of incubation, the foreign genotypes (H7996, AVTO 1713, AVTO 1717, LA 0442, LA 0443, LA 2701 and LA 0376) apart from LA 0716 showed significantly lower incidence and severity of wilt whiles all the local genotypes showed higher incidence and severity of wilt. However, there were no significant differences among LA 0716 and the local genotypes (Petofake, Power, Konkon, ATS 06 and P005). The genotypes H7996, LA 0442 and LA 0443 showed the lowest level of incidence (2.40) at the end of the experiment which were statistically not different from LA 0376 (2.83), AVTO 1717 (3.67) and LA 2701 (4.00). However, LA 0716 (7.71), CRI-P005 (8.70), Konkon (8.94), Power (9.05) and CRI-ATS 06 (9.31) which recorded high incidence levels were not significantly ( $p>0.05)$ different from Petofake (9.68) which was the susceptible check (Table III). Similarly, results indicated at the end of the experiment that, H7996 the resistant check showed the lowest level of severity (4.48) which was statistically the same as LA 0442 and LA 0443 (4.48) and were also not significantly $(\mathrm{p}>0.05)$ different from LA 0376 (5.35), AVTO 1717 (7.23) and LA 2701 (7.90). However, LA 0716 (15.36), CRI-P005 (17.36), Konkon (17.84), Power (18.06) and CRI-ATS 06 (18.58) which showed very high levels of severity were also not different from Petofake (19.33) the susceptible check (Table IV).

TABLE III: INCIDENCE OF BW AT DIFFERENT INCUBATION PERIODS

\begin{tabular}{ccccc}
\hline Genotypes & 1WAP & 2WAP & 3 WAP & $4 W A P$ \\
\hline H7996 & $0.71 \mathrm{a}$ & $0.71 \mathrm{a}$ & $0.71 \mathrm{a}$ & $2.40 \mathrm{a}$ \\
LA0376 & $0.71 \mathrm{a}$ & $0.71 \mathrm{a}$ & $2.83 \mathrm{ab}$ & $2.83 \mathrm{a}$ \\
LA 2701 & $0.71 \mathrm{a}$ & $0.71 \mathrm{a}$ & $2.83 \mathrm{ab}$ & $4.00 \mathrm{ab}$ \\
LA 0716 & $0.71 \mathrm{a}$ & $1.55 \mathrm{ab}$ & $5.47 \mathrm{bc}$ & $7.70 \mathrm{c}$ \\
LA 0442 & $0.71 \mathrm{a}$ & $0.71 \mathrm{a}$ & $1.55 \mathrm{a}$ & $2.40 \mathrm{a}$ \\
LA 0443 & $0.71 \mathrm{a}$ & $0.71 \mathrm{a}$ & $1.55 \mathrm{a}$ & $2.40 \mathrm{a}$ \\
AVTO 1717 & $0.71 \mathrm{a}$ & $0.71 \mathrm{a}$ & $0.71 \mathrm{a}$ & $3.67 \mathrm{ab}$ \\
AVTO 1713 & $0.71 \mathrm{a}$ & $1.55 \mathrm{ab}$ & $2.40 \mathrm{a}$ & $5.47 \mathrm{~b}$ \\
CRI-ATS06 & $0.71 \mathrm{a}$ & $4.43 \mathrm{c}$ & $6.55 \mathrm{c}$ & $9.31 \mathrm{c}$ \\
CRI-P005 & $0.71 \mathrm{a}$ & $3.25 \mathrm{bc}$ & $6.22 \mathrm{c}$ & $8.70 \mathrm{c}$ \\
Power & $0.71 \mathrm{a}$ & $5.29 \mathrm{c}$ & $6.84 \mathrm{c}$ & $9.05 \mathrm{c}$ \\
Konkon & $0.71 \mathrm{a}$ & $4.53 \mathrm{c}$ & $6.67 \mathrm{c}$ & $8.94 \mathrm{c}$ \\
Petofake & $0.71 \mathrm{a}$ & $5.47 \mathrm{c}$ & $7.33 \mathrm{c}$ & $9.68 \mathrm{c}$ \\
Grand mean & 0.71 & 2.33 & 3.97 & 5.89 \\
Sed & 0 & 1.01 & 1.31 & 1.06 \\
Fpr & NS & $<0.001^{* *}$ & $<0.001^{* *}$ & $<0.001^{* *}$
\end{tabular}

$\mathrm{BW}=$ Bacterial wilt, WAP $=$ Week after planting.

TABLE IV: SEVERITY OF BW AT DIFFERENT INCUBATION PERIODS

\begin{tabular}{ccccc}
\hline Genotypes & $1 \mathrm{WAP}$ & $2 \mathrm{WAP}$ & $3 \mathrm{WAP}$ & $4 \mathrm{WAP}$ \\
\hline H7996 & $0.71 \mathrm{a}$ & $0.71 \mathrm{a}$ & $0.71 \mathrm{a}$ & $4.48 \mathrm{a}$ \\
LA0376 & $0.71 \mathrm{a}$ & $2.59 \mathrm{ab}$ & $5.35 \mathrm{ab}$ & $5.35 \mathrm{a}$ \\
LA 2701 & $0.71 \mathrm{a}$ & $0.71 \mathrm{a}$ & $5.35 \mathrm{ab}$ & $7.90 \mathrm{ab}$ \\
LA 0716 & $0.71 \mathrm{a}$ & $2.59 \mathrm{ab}$ & $10.87 \mathrm{bc}$ & $15.36 \mathrm{~cd}$ \\
LA 0442 & $0.71 \mathrm{a}$ & $0.71 \mathrm{a}$ & $2.59 \mathrm{a}$ & $4.48 \mathrm{a}$ \\
LA 0443 & $0.71 \mathrm{a}$ & $0.71 \mathrm{a}$ & $2.59 \mathrm{a}$ & $4.48 \mathrm{a}$ \\
AVTO 1717 & $0.71 \mathrm{a}$ & $0.71 \mathrm{a}$ & $0.71 \mathrm{a}$ & $7.23 \mathrm{a}$ \\
AVTO 1713 & $0.71 \mathrm{a}$ & $2.59 \mathrm{ab}$ & $4.48 \mathrm{a}$ & $10.87 \mathrm{bc}$ \\
CRI-ATS06 & $0.71 \mathrm{a}$ & $8.77 \mathrm{c}$ & $13.05 \mathrm{c}$ & $18.58 \mathrm{~d}$ \\
CRI-P005 & $0.71 \mathrm{a}$ & $6.22 \mathrm{bc}$ & $12.38 \mathrm{c}$ & $17.36 \mathrm{~d}$ \\
Power & $0.71 \mathrm{a}$ & $10.50 \mathrm{c}$ & $13.62 \mathrm{c}$ & $18.06 \mathrm{~d}$ \\
Konkon & $0.71 \mathrm{a}$ & $8.98 \mathrm{c}$ & $13.21 \mathrm{c}$ & $17.84 \mathrm{~d}$ \\
Petofake & $0.71 \mathrm{a}$ & $10.87 \mathrm{c}$ & $14.61 \mathrm{c}$ & $19.33 \mathrm{~d}$ \\
Grand mean & 0.71 & 4.36 & 7.66 & 11.64 \\
Sed & 0 & 2.26 & 2.74 & 2.22 \\
Fpr & NS & $<0.001^{* *}$ & $<0.001^{* *}$ & $<0.001^{* *}$ \\
\hline
\end{tabular}

$\mathrm{BW}=$ Bacterial wilt, WAP $=$ Week after planting

C. Field screening of Bacterial Wilt Incidence and Severity of Tomato Genotypes

It was revealed from the results that, significantly high incidence and severity levels were recorded in the field experiment compared with the screen house situation. The same promising foreign genotypes AVTO 1713, AVTO 1717, LA 0442, LA 0443, LA 2701 and LA 0376 in the screen 
house experiment, recorded lower levels of incidence in the field experiment ranging from 2.10 to 12.50 (Table V) which were statistically the same as the resistant check H7996 (4.29). However, P005, ATS 06, Power and Konkon recorded very high incidence levels ranging from 22.92 to 33.33 which were however, significantly $(\mathrm{p}<0.05)$ lower than the susceptible check, Petofake (52.08) which recorded the highest level of incidence (Table V).

The genotypes LA 0442 and LA 0443 recorded lower severity indices of 2.15 and 3.60 respectfully which were lower than the resistant check H7996 (4.29) and LA0376 (4.29) but the observed differences among the genotypes were not significant. Genotypes LA 2701, AVTO 1713, AVTO 1717, CRI-P005, CRI-ATS 06, Power and Konkon had indices ranging from 6.42 to 23.98 and were significantly lower than the susceptible check (Petofake) which recorded the highest index of 28.5.

TABLE V: ASSESSMENT OF BW INCIDENCE AND SEVERITY

\begin{tabular}{ccc}
\hline Genotype & WI & WS \\
\hline H7996 & $4.20 \mathrm{a}$ & $4.29 \mathrm{ab}$ \\
LA0376 & $6.20 \mathrm{a}$ & $4.29 \mathrm{ab}$ \\
LA2701 & $12.50 \mathrm{ab}$ & $6.42 \mathrm{abc}$ \\
LA0442 & $2.10 \mathrm{a}$ & $2.15 \mathrm{a}$ \\
LA0443 & $4.20 \mathrm{a}$ & $3.60 \mathrm{a}$ \\
AVTO1717 & $12.50 \mathrm{ab}$ & $9.00 \mathrm{c}$ \\
AVTO1713 & $8.30 \mathrm{a}$ & $8.08 \mathrm{bc}$ \\
CRI-ATS06 & $27.10 \mathrm{c}$ & $19.69 \mathrm{~d}$ \\
CRI-P005 & $22.90 \mathrm{bc}$ & $19.12 \mathrm{~d}$ \\
Power & $29.20 \mathrm{c}$ & $21.40 \mathrm{~d}$ \\
Konkon & $33.30 \mathrm{c}$ & $23.18 \mathrm{~d}$ \\
Petofake & $52.10 \mathrm{~d}$ & $28.50 \mathrm{e}$ \\
Grand mean & 17.90 & 12.48 \\
Sed & 5.51 & 1.89 \\
FPr & $<0.001^{* *}$ & $<0.001^{* *}$ \\
\hline
\end{tabular}

$\mathrm{BW}=$ Bacterial wilt, $\mathrm{WI}=$ Wilt incidence $\mathrm{WS}=$ Wilt severity.

\section{Days to $50 \%$ Flowering}

It was observed that LA 0443 and LA 0376 which flowered in 28 and 29 days respectively were significantly $(\mathrm{p}<0.05)$ different from the resistant check $\mathrm{H} 7996$ which produced $50 \%$ flowering in 38 days. However, $\mathrm{H} 7996$ was not different from the susceptible check Petofake (41 days) and two other local genotypes (Konkon and CRI-P005) which flowered in 41 and 39 days respectively. On the other hand, the genotype Power took the maximum number of days (43) to produce $50 \%$ flowering which was not significantly different from the susceptible check Petofake (41 days) and two other resistant genotypes AVTO 1717 and AVTO 1713 which flowered in 42 and 42 days respectively (Table 6).

\section{E. Days to $50 \%$ Fruit Setting}

Results from Table VI showed that the genotype Power used a maximum number of 56 days to record $50 \%$ fruit setting which was statistically the same as CRI-ATS 06, AVTO 1713, AVTO 1717, Konkon and the susceptible check Petofake which set 50\% fruit at 55, 55, 55, 53 and 52 days respectively. However, LA0376 and LA 0443 used a minimum number of 46 days to record $50 \%$ fruit setting which were statistically the same as LA 0442, P005 and LA 2701 which used 48, 49 and 50 days for fruit setting respectfully but significantly $(\mathrm{p}<0.05)$ lower than the resistant check $\mathrm{H} 7996$ which used 51 days to record $50 \%$ fruit setting.

\section{F. Plant Height of Genotypes}

It was observed that LA 0443 recorded the tallest mean height of $71.00 \mathrm{~cm}$, which was statistically similar to both the resistant and susceptible checks: H7996 and Petofake, LA0376 and LA0442 (67.67, 65.00, 69.00 and $68.00 \mathrm{~cm})$ respectively. However, they varied significantly from the other genotypes. For instance, AVTO 1717 recorded the shortest mean height of $44 \mathrm{~cm}$ which was statistically similar to Power, CRI-ATS 06 and LA 2701 (which recorded 47.67, 50.67 and $45.67 \mathrm{~cm}$, respectively) but was significantly lower than both the resistant and susceptible (H7996 and Petofake) checks (Table VI).

\section{G. Stem Girth of Genotypes}

It could be inferred from (Fig. 3) that CRI-ATS 06 produced the largest mean stem girth $(1.27 \mathrm{~cm})$ which was not significantly different from the susceptible check Petofake $(1.17 \mathrm{~cm})$ but significantly $(\mathrm{p}<0.05)$ larger than the resistant check H7996 (0.87 cm). However, LA 0376 produced the smallest stem girth of $0.07 \mathrm{~cm}$ which was significantly $(\mathrm{p}<0.05)$ lower than both the susceptible (Petofake) and the resistant (H7996) checks.

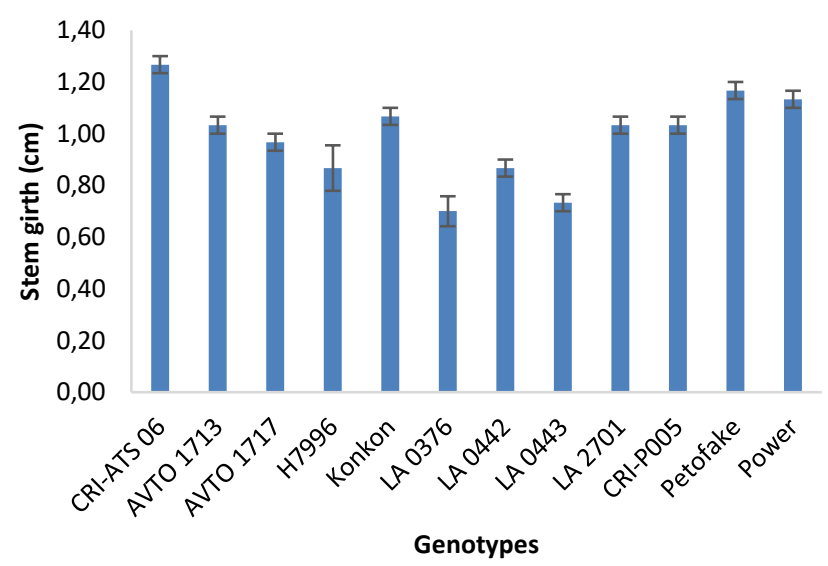

Fig. 3. Means and standard error bars of stem girth of genotypes as affected by $R$. solanacearum.

\section{H. Yield Performance of Genotypes}

The genotype LA 0442 produced the highest total yield of $50.67 \mathrm{t} / \mathrm{h}$ which was significantly $(\mathrm{p}<0.05)$ higher than the resistant H7996 $(24 \mathrm{t} / \mathrm{h})$ and the susceptible Petofake $(17.67 \mathrm{t} / \mathrm{h})$ and the same when the two are put together. The second highest yielding genotype LA 0443 (34 t/h) was however significantly lower than the highest yielder (LA 0442) but statistically higher than the resistant (H7996) and the susceptible (Petofake) checks as well as all the other genotypes evaluated in the field experiment (Table VI).

\section{Percent (\%) Total Soluble Solids (Brix)}

Fig. 4 presents the results of percent $(\%)$ total soluble solids. LA 2701 produced the lowest brix of 2.27 which was statistically the same as LA 0442 and the resistant check H7996 which produced 2.37 each. However, AVTO 1717 produced the highest brix level of 3.37 which was significantly $(\mathrm{p}<0.05)$ different from the susceptible check Petofake (2.60) and the other genotypes LA 0443, CRI-P005, Power, Konkon, AVTO 1713, CRI-ATS 06 and LA 0376 which produced brix levels ranging from 2.60 to 3.17 . 


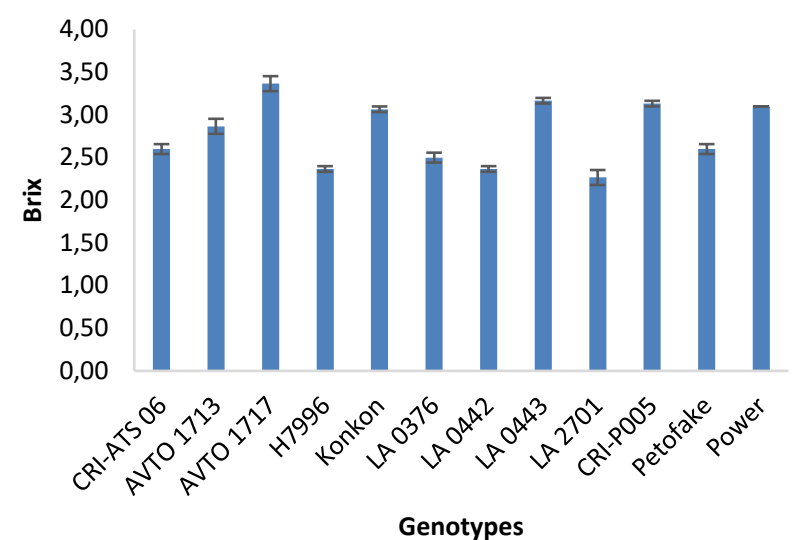

Fig. 4. Means and standard error bars of total soluble solids of genotypes as affected by $R$. solanacearum.

\section{J. Locule Numbers}

Results from Fig. 5 revealed that two of the genotypes (CRI-ATS 06 and Power) recorded significantly high locule numbers (6 each). However, they were not significantly $(\mathrm{p}>0.05)$ different from Petofake and P005 which recorded 5 locules each. Three of the genotypes (LA 0442, LA 0443, and LA 0376) developed significantly $(\mathrm{p}<0.05)$ lower locule numbers (2 each) which were not different from H7996, LA 2701 and AVTO 1713 which developed 3 locules per fruit. In addition, two other genotypes (Konkon and AVTO 1717) developed significantly high number of locules (4 each) which were higher than the resistant check (H7996) but significantly lower than the susceptible check (Petofake).

TABLE VI: CHARACTERISTICS OF TOMATO GENOTYPES

\begin{tabular}{ccccc}
\hline Genotypes & DF $(50 \%)$ & $\begin{array}{c}\text { DFS } \\
(50 \%)\end{array}$ & $\begin{array}{c}\text { Yield } \\
(\mathrm{t} / \mathrm{ha})\end{array}$ & PH $(\mathrm{cm})$ \\
\hline H7996 & $37 \mathrm{c}$ & $51 \mathrm{cde}$ & $24.00 \mathrm{~cd}$ & $67.67 \mathrm{ef}$ \\
LA0376 & $29 \mathrm{a}$ & $45 \mathrm{a}$ & $31.00 \mathrm{de}$ & $69.00 \mathrm{f}$ \\
LA2701 & $37 \mathrm{c}$ & $48 \mathrm{cde}$ & $16.33 \mathrm{abc}$ & $45.67 \mathrm{ab}$ \\
LA0442 & $33 \mathrm{~b}$ & $50 \mathrm{bcd}$ & $50.67 \mathrm{f}$ & $68.00 \mathrm{f}$ \\
LA0443 & & $46 \mathrm{ab}$ & $34.00 \mathrm{e}$ & $71.00 \mathrm{f}$ \\
AVTO1717 & $28 \mathrm{a}$ & $54 \mathrm{de}$ & $15.67 \mathrm{abc}$ & $44.00 \mathrm{a}$ \\
AVTO1713 & $42 \mathrm{de}$ & $54 \mathrm{de}$ & $12.67 \mathrm{a}$ & $59.00 \mathrm{cde}$ \\
CRI-ATS06 & $42 \mathrm{de}$ & $55 \mathrm{de}$ & $23.00 \mathrm{bcd}$ & $50.67 \mathrm{abc}$ \\
CRI-P005 & $42 \mathrm{de}$ & $49 \mathrm{abc}$ & $18.00 \mathrm{abc}$ & $53.67 \mathrm{bc}$ \\
Power & $39 \mathrm{~cd}$ & $55 \mathrm{e}$ & $13.67 \mathrm{ab}$ & $47.67 \mathrm{ab}$ \\
Konkon & $41 \mathrm{cde}$ & $53 \mathrm{cde}$ & $15.00 \mathrm{abc}$ & $57.00 \mathrm{~cd}$ \\
Petofake & $41 \mathrm{cde}$ & $51 \mathrm{cde}$ & $17.00 \mathrm{abc}$ & $65.00 \mathrm{~cd}$ \\
Grand mean & 38 & 51 & 22.64 & 58.19 \\
Sed & 2.00 & 2.00 & 4.18 & 4.08 \\
FPr & $<0.001 * *$ & $<0.001^{* *}$ & $<0.001 * *$ & $<0.001 * *$ \\
\hline
\end{tabular}

$\mathrm{DF}=$ Days to flowering; DFS $=$ Days to fruit setting; $\mathrm{PH}=$ Plant height.

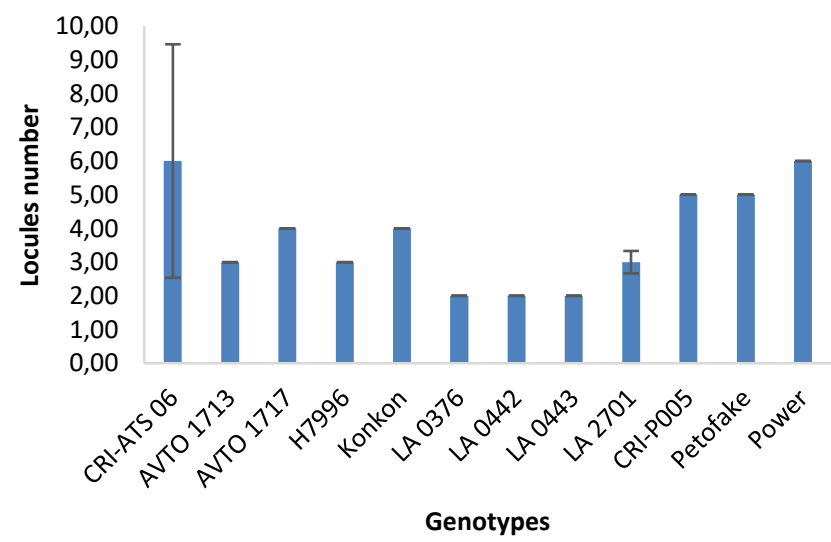

Fig. 5. Means and error bars of locule numbers of genotypes as affected by $R$. solanacearum.

\section{DISCUSSION}

This study confirmed $R$. solanacearum as the causal organism of bacterial wilt disease affecting tomato production in Ashanti and Brong-Ahafo regions in Ghana. Previous authors [14] had reported that the bacterium is responsible for tomato wilt in Ghana. According to [20], tomato production has a high capital input, however high returns could easily be realized due to high market demands for good and quality crop. However, bacterial wilt disease $(R$. solanacearum) is a major limiting factor in the production of the crop, threatening farmers' profit margins.

Five different isolates, all negative gram stained, and rod shaped were identified from the two regions studied. White Irregular (WI) isolates dominated the samples and represented $30 \%$ followed by White Circular Small (WCS) $20 \%$, Cream Irregular (CI) 20\%, Irregular (I) $20 \%$ and White Circular Large (WCL) constituted 10\%, the least encountered in the samples. The pathogen is a soil-borne bacterium and survives in soil, water, and plant materials for prolonged periods [21] and to prevent the spread of pathogen, it is important to use clean seeds, uninfected soil, water, and tools in the production of the crop [22].

Strains from Ashanti and Brong-Ahafo regions of Ghana were identified as Phylotype II from America. This is in agreement with [23] who described the strain classification system consisting of four Phylotypes (Phylotypes I, II, III and IV). However, the Phylotype II, III and IV strains were not identified in the study areas. Researchers [14] identified Phylotype I and Phylotype III on tomato as the first report of $R$. solanacearum in Ghana and according to [24], Phylotypes I, III and IV were identified from samples from greenhouse in Southern Ghana. The introduction of these strains could be the result of exchange of infected planting materials (seeds and substrate) in the country [25]. In addition, contaminated irrigation water may be responsible for the spread from one community to the other [26]. However, seeds have been implicated as the potential source of spread [27]. It is important to identify the Phylotype implicated in order to adopt an appropriate management and control strategy because a variety said to be resistant to a particular Phylotype can be susceptible to another in the same or different environment [28].

The lower the level of BW disease incidence and severity, the higher the resistance level [29]. From this study, genotypes LA 0442, LA 2443, LA 0376 and H7996 recorded the lowest levels of incidence and severity of the BW disease throughout the study. The variation in the level of BW incidence and severity among the tomato genotypes observed in this study could be due to the differences in their genetic makeup as reported by [30] who screened 27 cultivars for resistance to bacterial wilt disease and identified resistant genotypes with low mean disease severity scores in several genotypes including Hawaii 7996, BWR-20, Spider, High Power, IT 201664, Hawaii 7998, and Fighting. Comparing the resistance level using the susceptible check Petofake as a reference, H7996, LA 0442 and LA 0443 were of higher resistance to BW disease followed by LA 0376, AVTO 1717 and LA 2701. They also showed a significantly lower level of incidence and severity of wilt compared to AVTO 1713 and Power. The current results are in consonance with a similar 
study by [31] who reported that H7996 expressed the highest level of resistance to bacterial wilt in tomato in Taiwan. It is important to note in the field study that, genotypes LA 0442, LA 0443 and H7996 were resistant to BW disease and therefore could be used as parental lines to improve BW susceptible varieties. In addition, results of this current study revealed that among the genotypes showing resistance to BW disease incidence and severity, H7996, LA 0442 and LA 0443 expressed significant levels of stability both in the screen house and field evaluations. This is in line with report by previous authors [18], when examination of some inbred lines derived from $\mathrm{H} 7996$ was conducted.

Flowering in tomato is very important because it has a greater impact on the potential yield of the crop. A high rate of flower buds drop may result in a drastic reduction in yield and this can be of a greater disadvantage in cultivars for single harvest. Flowering differed significantly among tomato genotypes studied which agrees with [31]. The days required for $50 \%$ flowering were minimum (28 and 29 days) in LA 0443 and LA 0376 respectively while flowering delayed maximum in CRI-ATS06, AVTO1713, AVTO1717 and Petofake (42, 42, 42 and 41) days respectively. From the results, it could be observed that BW severity did not influence the number of days to $50 \%$ flowering. The resistant check $\mathrm{H} 7996$ used 38 days to attain $50 \%$ flowering which was comparable to the susceptible check Petofake which used 41 days.

Fruit setting is an equally important component of yield in tomato crop since it gives an idea on the estimated yield of the crop if all conditions remain constant. Therefore, the higher the number of fruit set, the higher the yield and vice versa. The current study considered $50 \%$ fruit setting, whilst in an earlier study by [32] the study focused on fruit setting initiation. Fifty (50) per cent fruit setting and fruit setting initiation are critical in tomato production and both parameters could be used in determining the potential yield of the crop. It was reported in that study [32] that the cultivar "Samarzano" took a maximum of 27 days to initiate fruit setting while "Nadir" took a minimum of 16 days. In this study, Power used a maximum number of 56 days in producing $50 \%$ fruit setting which was statistically the same as the bacterial wilt susceptible check Petofake which used 55 days for $50 \%$ fruit setting. However, LA0376 and LA 0443 used a minimum number of 46 days to produce $50 \%$ fruit setting which was significantly $(\mathrm{p}<0.05)$ lower than the bacterial wilt resistant check H7996 which used 51 days to set fruit. However, in both studies, the differences in time taken to initiate fruit setting and attaining 50\% fruit setting might be due to the genetic make-up of the different experimental materials.

The results on plant height were expected as different genotypes exhibited different plant heights. The tallest genotype, LA 0443 was $38 \%$ taller than the shortest, AVTO 1717. The reasons for the differences in height could be attributed to genetic, biotic, and abiotic factors. Similarly, differences in stem girth might be due to the genetic constitution of the genotypes as well as the environmental effects. The largest stem girth in ATS06 was approximately 94\% larger than the smallest girth in LA 0376.

The yield results from this study also revealed the importance of obtaining high yielding varieties from genotypes that are resistant to BW disease. These genotypes could subsequently be used in future improvement programs to develop tomato varieties with BW resistance. However, variations observed in yielding ability by genotypes could be attributed to the number of flowers set that developed into fruits and preserved by the genotypes until harvest which are predicated on genetic considerations. This result is similar to the reports on differences in fruit yield among different tomato varieties [33]-[35]. In a similar study, [32] reported the highest yield of $41.45 \mathrm{t} / \mathrm{h}$ in "Tanja" and the lowest of $26.07 \mathrm{t} / \mathrm{h}$ in "Rio Grande". In the current study, apart from the highest yielding genotype LA $0442(50.67 \mathrm{t} / \mathrm{h})$, the rest of the genotypes recorded very low yields. For instance, the lowest yielding genotype AVTO 1713, recorded (12.67 t/h). Thus, the highest yielding genotype, LA 0442 over-yielded the lowest by approximately $300 \%$. The significant differences in yield might be attributed to genetic factors as well as the effect of bacterial wilt disease in some of the genotypes.

Brix is a measure of the Total Soluble Solids (TSS) content in the tomato or tomato product, and it is related to the taste. TSS in tomato is mainly sugars (fructose). Tomato juice assessed as having 20 Brix, has $200 \mathrm{~g} /$ litre of soluble sugars. Tomato for processing require a minimum Brix of 4.5. The highest yielding Brix, AVTO1717 out-yielded LA 2701 the lowest yielder by approximately $32.64 \%$. However, virtually all the genotypes studied fell below the minimum processing Brix requirement level of 4.5 .

In tomato, the number of locules (cavities containing seeds that are derived from carpels) varies from two to 10 or more. Locule number is controlled by quantitative trait loci [36]. The number of locules in tomato affects the fruit size, shape, and the incidence of malformation [37]. Therefore, the higher the locule number, the less attractive the tomato crop and the lower the price. In this study, it was observed that locule numbers ranged from 2 to 6 where fruits with locule number two looked smaller in size. Fruits with locule numbers three and four looked bigger in size with attractive shape. However, fruits having more than four locules looked bigger in size yet not attractive in shape.

The identification of resistant genotypes and subsequent incorporation into the tomato breeding program would reduce the challenge of managing $\mathrm{BW}$ disease and increase the productivity of tomato in the disease prone areas in Ghana.

\section{CONCLUSION}

The study confirmed that the bacterium, Ralstonia solanacearum is the causal agent of bacterial wilt disease. However, three bacterial wilt resistant genotypes; H7996, LA 0442 and LA 0443 were found promising, regarding the expression of significant stability in terms of very low incidence and severity levels in the two environments (screen house and field) in which the experiments were conducted. The good qualities observed in some of the resistant genotypes based on their acceptable horticultural characteristics [38] highlight the potential of developing at least a cultivar resistant to BW disease. The effort would enhance the productivity of the tomato crop and generally improve the profitability of the tomato industry in Ghana. 


\section{ACKNOWLEDGEMENT}

This study was funded by the UK AID Vegetable Seed System and KOPIA project. Authors are highly indebted to the Program Leaders; Mr. Offei-Bonsu and Dr. Michael Osei Kwabena respectively for the financial assistance. Data gathered from the study enabled Isaac Newton BoakyeMensah to complete a Master of Philosophy degree at CCST, Kumasi, Ghana.

\section{REFERENCES}

[1] J. Van Asselt, I. Masias, S. Kolavall, Competitiveness of the Ghanaian vegetable sector: Findings from a farmer survey. Accra: International Food Policy Research Institute, GSSP Working Paper 47, 2018.

[2] L. Siracusa, C. Patanè, V. Rizzo, S.L. Cosentino and G. Ruberto, Targeted secondary metabolic and physico-chemical traits analysis to assess genetic variability within a germplasm collection of "long storage" tomatoes, Food Chemistry, 244, 275-283, 2018.

[3] G.R. Beecher, Nutrient content of tomatoes and tomato products. Experimental Biology and Medicine, 218, 98-100, 1998

[4] A. Raffo, C. Leonardi, V. Fogliano and P. Ambrosino, Nutritional value of cherry tomatoes (Lycopersicon esculentum cv. Naomi F1) harvested at different ripening stages. Journal of Agriculture and Food Chemistry, 50, 6550-6556, 2002.

[5] D. Bhowmik, K.P. Sampath Kumar, S. Paswan and S. Srivastava, Tomato- a natural medicine and its health benefits. Journal of Pharmacognosy and Phytochemistry, 1(1), 24-36, 2012.

[6] K. Prasannath, K.N.P. Dharmadasa, D.M. De Costa and K.S. Hemachandra, Variations of incidence, types of virus diseases and insect vector populations of tomato (Solanum lycopersicum L.), grown in different agroecological regions of Sri Lanka under two crop management systems, Tropical Agricultural Research, 25(3), 376-395, 2014.

[7] A.I. Huerta, A. Milling and C. Allen, Tropical strains of Ralstonia solanacearum outcompete race 3 biovar 2 strains at lowland tropical temperatures. Applied Environmental Microbiology, 81(10), 35423551, 2015.

[8] N. Peters, A. Guidot, F. Vailleau and M. Valls, Ralstonia solanacearum, a widespread bacterial plant pathogen in the postgenomic era, Molecular Plant Pathology, 14, 651, 2013.

[9] C.A, Lopes, M. Rossato and L.S. Boiteux, The host status of coffee (Coffeae arabica) to Ralstonia solanacearum phylotype I isolates. Tropical Plant Pathology, 40: 1-4, 2015.

[10] N. Kazuhiro and A.A. Caitilyn, Pectinase-deficient Ralstonia solanacearum strain induces reduced and delayed structural defences in tomato xylem. Journal of Phytopathology, 157, 228-234, 2009.

[11] J. Huang, L. Yan, Y. Lei, H. Jiang, X. Ren and B. Liao, Expressed sequence tags in cultivated peanut (Arachis hypogaea): Discovery of genes in seed development and response to Ralstonia solanacearum challenge, Journal of Plant Research, 125, 755-769, 2012.

[12] B. Álvarez, M.M. López and E.G. Biosca, Influence of native microbiota on survival of Ralstonia solanacearum phylotype II in river water microcosms. Applied Environmental Microbiology, 73, 72107217, 2007.

[13] B. Álvarez, M.M. López and E.G. Biosca, Survival strategies and pathogenicity of Ralstonia solanacearum phylotype II subjected to prolonged starvation in environmental water microcosms. Microbiolology, 154:3590-3598, 2008.

[14] N. Subedi, R.L. Gilbertson, M.K. Osei, E. Cornelius and S.A. Miller, First report of bacterial wilt caused by Ralstonia solanacearum in Ghana, West Africa. Plant Disease 98(6), 840, 2014.

[15] T.P. Mamphogoro, O.O. Babalola, O.A. Aiyegoro, Sustainable management strategies for bacterial wilt of sweet peppers (Capsicum annuиm) and other Solanaceous crops. Journal of Applied Microbiology, 129, 496-508, 2020.

[16] M.J. Kwak, H.G. Kong, K. Choi, S.K. Kwon, J.Y. Song, J. Lee and E.J. Jung, Rhizosphere microbiome structure alters to enable wilt resistance in tomato. Nature Biotechnology, 36 (11), 1100-1109, 2018.

[17] A.L. Botta, A. Santacecilia, C. Ercole, P. Cacchio and M. Del Gallo, In vitro and in vivo inoculation of four endophytic bacteria on Lycopersicon esculentum. New Biotechnology, 30 (6), 666-674, 2013.

[18] J.F. Wang, F.I. Ho, H.T.H. Truong, S.M. Huang, C.H. Balatero, V. Dittapongpitch and N. Hidayati, Identification of major QTLs associated with stable resistance of tomato cultivar 'Hawaii 7996'to Ralstonia solanacearum, Euphytica 190 (2), 241-252, 2013.
[19] M.N. Aslam, T. Mukhtar, M.A. Hussain and M. Raheel, Assessment of resistance to bacterial wilt incited by Ralstonia solanacearum in tomato germplasm. Journal of Plant Diseases and Protection, 124(6), 585590, 2017.

[20] A. Elings, Y. Saavedra, G.O. Nkansah, Strategies to support the greenhouse horticulture sector in Ghana. Wageningen UR. No. 1353, 2015.

[21] M.M. Lopez and E.G. Biosca, Potato bacterial wilt management: new prospects for an old problem. Bacterial wilt disease and the Ralstonia solanacearum species complex, pp. 205-224, 2005.

[22] F. Meng, The virulence factors of the bacterial wilt pathogen Ralstonia solanacearum. Journal of Plant Pathology and Microbiology, 4(168), 10-4172, 2013

[23] M. Fegan and P. Prior, How complex is the Ralstonia solanacearum species complex. APS Press, pp. 449-461. 2005.

[24] N.Y. Sarfo, Importance, source and control of bacteria wilt disease in greenhouse Tomato (Solanum Lycopersicum L.) in southern Ghana, Doctoral Dissertation, University of Ghana, 2018.

[25] A.L. Garcia, W.G. Lima, E.B. Souza, S.J. Michereff and R.L.R. Mariano, Characterization of Ralstonia solanacearum causing bacterial wilt in bell pepper in the state of Pernambuco, Brazil. Journal of Plant Pathology, 95 (2), 237-245, 2013.

[26] Waiganjo MM, Wabule NM, Nyongesa D, Kibaki JM, Onyango I, Wepukhulu SB, Muthoka NM (2006) Tomato production in Kirinyaga district, Kenya, a baseline survey report. Kenya Agricultural Research Institute, Nairobi, Kenya, 1-43.

[27] A. Abdurahman, D. Griffin, J. Elphinstone, P.C. Struik, S. Schulz, E. Schulte-Geldermann and K. Sharma, Molecular characterization of Ralstonia solanacearum strains from Ethiopia and tracing potential source of bacterial wilt disease outbreak in seed potatoes. Plant Pathology, 66 (5), 826-834. 2017.

[28] V. Sager, A. Jeevalatha, S. Mian, S.K. Chakrabarti, M.S. Gurjar, R.K. Arora and B.P.Singh, Potato bacterial wilt in India caused by strains of phylotype I, II and IV of Ralstonia solanacearum, European Journal of Plant Pathology, 138 (1), 51-65,2014.

[29] X. Li, S. Shin, S. Heinen, R. Dill-Macky, F. Berthiller, N. Nersesian and G.J. Muehlbauer, Transgenic wheat expressing a barley UDPglucosyltransferase detoxifies deoxynivalenol and provides high levels of resistance to Fusarium graminearum. Molecular PlantMicrobiology International, 28(11), 1237-1246, 2015.

[30] A.M. Abebe, J. Choi, Y. Kim, C.S. Oh, I. Yeam, I.S. Nou and J.M. Lee, Development of diagnostic molecular markers for marker-assisted breeding against bacterial wilt in tomato. Breeding Science, 70 (4), 462-473, 2020.

[31] J.F. Wang, P. Hanson, J.A. Barnes, Worldwide evaluation of an international set of resistance sources to bacterial wilt in tomato. In Bacterial Wilt Disease, 269-275. Springer, Berlin, Heidelberg, pp 269 275, 1998.

[32] S.I. Hussain, K.M. Khokhar, T. Mahmood, M.H. Laghari and M. Mahmud, Yield potential of some exotic and local tomato cultivars grown for summer production. Pakistan Journal of Biological Sciences, 4 (10), 1215-1216, 2001.

[33] S. Das, Performance of exotic tomato lines at Sher-e-bangla Agricultural University, Doctoral Dissertation, Department of Horticulture, 2017.

[34] G. Gongolee, M.K. Osei, R. Akromah, D. Nyadanu and L.M. Aboagye, Evaluation of some introduced tomato cultivars. Horizon Journal of Agriculture and Food Science, 1(1), 1-4. 2015.

[35] L.D. Meloney, Development of high yielding tomato lines with resistance to tomato yellow leaf curl disease (TYLCD). Doctoral Dissertation, University of Ghana, 2018.

[36] S. Munos, N. Ranc, E. Botten, A. Berard, S. Rolland, P. Duffe, Y. Carreero, M-C. Le Paslier, C. Dehalande, M. Bouzayen, D. Brurel and M. Causse, Increase in tomato locule numbers controlled by two singlenucleotide polymorphisms located near WUSCHEL, Plant Physiology, 156 (4), 2244-2254, 2011

[37] Y. Li, M. Sun, H. Xiang, Y. Liu, H. Li, M. Qi and T. Li, Low overnight temperature-induced gibberellin accumulation increases locule number in tomato. International Journal of Molecular Science, 20(12), 3042, 2019.

[38] J.F. Wang, J. Olivier, P. Thoquet, B. Mangin, L.Sauviac and N.H. Grimsley, Resistance of tomato line Hawaii7996 to Ralstonia solanacearum Pss4 in Taiwan is controlled mainly by a major strainspecific locus, Molecular Plant-Microbiology International, 13(1), 6 13,2000 . 